\title{
Developing a framework for the monitoring and evaluation of the Health Transformation Plan in the Islamic Republic of Iran: lessons learned
}

Zhaleh Abdi, ${ }^{1}$ Reza Majdzadeh ${ }^{2}$ and Elham Ahmadnezhad ${ }^{1}$

${ }^{1}$ National Institute of Health Research, Tehran University of Medical Sciences, Tehran, Islamic Republic of Iran. ${ }^{2}$ Knowledge Utilization Research Center, Community Based Participatory Research Center, National Institute of Health Research, Department of Epidemiology and Biostatistics, Tehran University of Medical Sciences, Tehran, Islamic Republic of Iran. (Correspondence to: Elham Ahmadnezhad: ahmadnezhad@tums.ac.ir).

\begin{abstract}
Background: Monitoring and evaluation of health system reforms are essential to ensure the achievement of their objectives. The latest heath sector reform in the Islamic Republic of Iran, namely, the Health Transformation Plan (HTP), was launched in 2014 and the country is embarking on the HTP to achieve universal health coverage (UHC).
\end{abstract}

Aims: The study aimed to develop the most appropriate monitoring and evaluation framework for the HTP in accordance with national and global goals and priorities, and to identify data gaps in its monitoring and evaluation.

Method: A case study and evidence-based approach was applied to develop the monitoring and evaluation framework. The model that was proposed jointly by the World Bank and the World Health Organization for monitoring and evaluation of UHC was used as the basis for the potential list of the indicators and key policy documents were reviewed, accordingly. The framework formulation process was carried out through a series of meetings with experts and senior managers working at the Ministry of Health and Medical Education, whose perspectives on the frameworks functionality and usage were regarded as valuable. The final draft was presented to policy-makers for input and approval.

Results: A data mapping revealed that at least nine national surveys were required to obtain the indicators for effective monitoring. At the time of framework designing, many indicators were not available or had not been updated for several years due to lack of available and appropriate data sources.

Conclusions: Results indicated that the country's health information system had many information gaps that should be filled to enable the tracking of UHC goals and measuring the success of the plan. Applying the proposed framework would increase the comparability of the country's health indicators at the global level and specify a path to successfully achieve the objectives of the reform.

Keywords: reform, monitoring and evaluation, universal health coverage, global health, Iran

Citation: Abdi Z; Majdzadeh R; Ahmadnezhad E. Developing a framework for the monitoring and evaluation of the Health Transformation Plan in the Islamic Republic of Iran: lessons learned. East Mediterr Health J. 2019;25(6):394-405. https://doi.org/10.26719/emhj.18.067

Received: 19/06/16; accepted: 13/08/18

Copyright (C) World Health Organization (WHO) 2019. Some rights reserved. This work is available under the CC BY-NC-SA 3.0 IGO license (https:// creativecommons.org/licenses/by-nc-sa/3.o/igo).

\section{Introduction}

Timely monitoring and evaluation (M\&E) of health system reforms is critical in order to identify the achievements of their objectives. M\&E is a matter of great importance for two reasons: first, it can play a significant role in assessing the extent to which the reforms have achieved their goals; second, it may create a constructive environment for a dialogue among stakeholders by building a common language among them $(1,2)$.

In recent decades, the Islamic Republic of Iran's health system has witnessed various structural and organizational changes. However, it still faces important challenges related to the accessing of health services and fair financial contributions of households to the financing of the health system (3-5). There are several reasons for the lack of success of health reforms in the country. Among the most important ones are lack of adequate political support and inadequate budgetary allocation for the health sector (5). According to the report of the core indicators for the monitoring of the health situation and health system performance prepared by the World Bank (6), Iranian households paid almost $47.2 \%$ of expenditures as out of pocket payment for health in 2013. The proportion of households that incur catastrophic health expenditure was estimated to be between $6 \%$ and $24 \%$ in different parts of the country. According to the results of these studies, $1.5-11 \%$ of households suffered poverty due to healthcare related expenditures (7-12).

The Islamic Republic of Iran's General Health Policies were endorsed in 2014 (4). The policy, which requires fundamental changes in the health system, is to be implemented by 2025. Accordingly, the government prioritized health system reforms and kept them at the top of its agenda. The latest health sector reform - the Health Transformation Plan (HTP) - was launched in May 2014 to ensure the protection of Iranians against financial risks, increasing equity in accessing services, and improving the quality of services $(3,13,14)$. The HTP had one primary phase and three main phases in the beginning. Given the shortage of medicines due to international sanctions, the Ministry of Health and 
Medical Education (MoHME) took major steps to remove the shortage of essential medicines and reduce the prices of medicines in early 2014. The first phase of the HTP, which included eight main interventions aimed at increasing people's access to hospital services (particularly in-patient services), was implemented in April 2014. These interventions involved insuring around 11 million people, who did not have any health insurance. The next phase encompassed interventions to strengthen the Primary Health Care (PHC) system and to ensure that the PHC functioned more efficiently. Owing to a high incidence of informal payment, the third phase, launched in November 2014, aimed at reducing and eradicating informal payments in the health sector. Since insufficient provider remuneration has been identified as the most important factors motivating informal payments among Iranian health care providers, the main objective of the third phase was to address physicians' payments and the setting of their payments in both the public and private sectors $(8,15)$.

The Islamic Republic of Iran's National Institute of Health Research (NIHR), which is responsible for providing evidence to health policy-makers, was entrusted with the responsibility of M\&E of the HTP (15). The latter was initiated in June 2014, a few weeks after the commencement of the HTP. In the absence of any baseline data, it was difficult to evaluate any changes made due to the HTP implementation at the beginning of the plan (16). Given this limitation, two short-term and long-term approaches were used to monitor and evaluate the HTP. In the short-term approach, an evaluation of the HTP was done using the readily available data. Within this approach, patient and staff experience and satisfaction as well as the financial risk protection of households were assessed.

One of the main goals of the HTP was to create satisfaction among patients receiving services from hospitals affiliated to the MoHME (15). Consequently, several small surveys assessing patients' and service providers' satisfaction were designed and implemented by the NIHR. The studies commenced from the summer of 2014 and were conducted seasonally until the time of writing this article. The results were reported regularly to the policy-makers $(15,17)$. For more than 20 years, the National Center of Statistics (NCS) conducted periodic household surveys to assess the living standards of Iranian households. The NIHR used the disaggregated NCS health expenditures data to provide policy-makers with the number of households that incurred catastrophic health expenditures or became impoverished before and after the introduction of the HTP. Apparently, indicators of satisfaction and financial contribution of households were not sufficient to fully demonstrate the changes and challenges brought about by the HTP implementation. Conducting a comprehensive evaluation necessitated an M\&E framework for the plan. The current study aimed to develop the most appropriate M\&E framework for the HTP and identify the data gaps to enable proper monitoring and evaluation.

\section{Methods}

\section{The national monitoring and evaluation framework}

\section{Development pathway of M\&E framework}

A case study and evidence-based approach was applied to develop an $M \& E$ framework. No specific $M \& E$ framework had been developed for M\&E of the HTP at the time of designing. Considering the fact that the HTP was introduced to hasten the country's attainment of UHC, it was agreed upon to design a framework that simultaneously monitored the reform implementation and assessed the progress towards UHC. The global M\&E proposed framework for UHC published by the World Health Organization (WHO) in collaboration with the World Bank (18), was used as the basic framework of this study. This model has been accepted for UHC tracking by all WHO Member States. It is proposed that every country develop its own framework based on its contextual factors, macro-policies, and health programmes. Accordingly, government policy documents were reviewed to determine the policies the addressed the UHC goals and objectives.

UHC ensures that those who need health services receive them without facing financial hardship. It is perceived as a crucial component of sustainable development and listed as one of the possible goals of the post-2015 development agenda $(19,20)$. Various countries develop and refine their own approaches to UHC, depending on their levels of economic development, health system, and epidemiological challenges. Moving toward UHC requires technically sound definitions and metrics to measure progress. Therefore, it is essential to identify appropriate approaches, comparable but adaptable to local contexts, to measure UHC progress across countries (2).

A review of a wide range of national and health sector documents was done to provide in-depth understanding of the national commitment for reaching UHC. In three out of 14 articles of the country's general health policies, certain aspects of the UHC such as the necessity of sustainable health sector financing, expansion of the cove rage of basic health insurance, and the deepening of the insurance coverage have been directly argued. In other upstream documents of the country such as the country's fifth national development plan (2011-2015) (16), a number of UHC objectives including financial protection, coverage, and equitable access to health care services have been mentioned. It has been recommended that, through the sixth development plan $(3,16)$, the country should achieve the UHC objectives by $2025(8,21)$.

The implementation of the HTP as the health system reform can accelerate the progress toward the UHC in the Islamic Republic of Iran. As mentioned before, it was decided to design a framework that simultaneously monitored the HTP implementation and tracked UHC progress. The NIHR initiated the development of the framework indicators and their metadata in a few months after the HTP implementation. The development of the 
metadata clarified the data requirements for monitoring progress toward UHC and current information gaps that could influence UHC monitoring.

Development of the indicators list consisted of three main steps: determination of the indicators, identification of data sources and measurement methods, and ensuring of appropriate disaggregation of the indicator. A rapid review of the country information system was conducted to understand country data availability and quality, data sources, flows and structures. The indicators were developed and classified, according to the objectives of the HTP and UHC, and the local context. While selecting the indicators, effort was made to retain a breadth of indicators to cover a range of health interventions. The following criteria were considered to select indicators:

- Aligning with national and international commitments;

- ensuring data are available or can be collected or monitored with a reasonable resource;

- selecting indicators in accordance with the country's health needs;

- reflecting all domains in the M\&E framework from input to impact;

- considerations of relevance, technically accurate with a measurable numerator and denominator, usefulness for decision-making, and data availability; and

- ensuring where possible indicators can be disaggregated for equity analysis.

A set of metadata for the proposed framework indicators was developed. Steps to be taken to ensure appropriate data collection to develop the indicators were further discussed. Clearly defining data sources and measurement frequency were among the most important steps of the framework development. Since the achievement of equity is implicit in the UHC goals, disaggregation of the indicators by the main equity stratifiers is critical to monitor progress in all population groups. Therefore, in the proposed framework, the indicators were disaggregated by place of residence (urban/rural), sex (male/female), socio-economic status (wealth quintiles), and other relevant equity stratifies.

The framework formulation process was carried out through a series of meetings and workshops with experts and senior managers working at different departments of the MoHME whose perspectives on the frameworks functionality and usage were regarded as valuable. The involvement of different MoHME departments and divisions was important in order to ensure ownership and commitment. During these consultative discussions, operational issues related to the proposed indicators, their availability, and feasibility were discussed. Relevant feedback from the participants was incorporated in the final draft, which was presented to policy-makers for input and approval. The M\&E framework was approved and agreed upon as a framework for the monitoring and evaluation of both the HTP and UHC by high-level policymakers, including deputy minsters.

\section{Results}

The list of the proposed indicators contains eight tracer indicators of financing, six indicators of infrastructure and health workforce, two indicators of health information system, 15 indicators of access to and coverage of health services, five indicators of the utilization of health services, nine indicators of service quality and safety, 13 indicators of effective coverage of services, 12 indicators of health risk factors, 11 indicators of health status, two indicators of financial risk protection and three indicators of satisfaction with health services (Appendix A). In the data mapping (Table 1), data availability at the time of framework designing, data sources, responsible agencies for data collection, and the required frequency of data collection were considered. Indicators of the M\&E framework could be categorized into four main domains:

a) Input consists of three main categories including financial protection, human workforce, and infrastructures and information system;

b) output consists of four categories of indicators including access, coverage, utilization, and quality and safety;

c) outcome, which is practically the most important part of the M\&E framework (due to lack of information), comprises indicators of effective coverage and the risk factors. The measurement of these indicators allows a comparative assessment of the health interventions at the global level; and

d) impact contains indicators related to health status, satisfaction, and financial risk protection.

According to the framework, at least nine national surveys are required to develop framework indicators (Table 2). Following the M\&E framework development, the NIHR decided to investigate the coverage and utilization of the health services among the Iranian population. Hence, two household surveys - the Healthcare Coverage and Utilization Survey (22) (investigating access to and coverage of medical care) and the country's Multiple Indicators Demographics and Health Survey (23) (IrMIDHS-investigating access to and coverage of primary health care) - were designed and implemented in 2014 and 2015 at the national level by the NIHR.

In general, there were gaps in available data required to track indicators and monitor progress toward UHC at the time of framework development. Among the selected indicators, almost half of them had already been tracked by the routine health information system and ongoing surveys. A number of indicators were not available or had not been updated for several years. No appropriate data sources were available for the rest. Furthermore, the available indicators did not describe the differences and changes in health indicators in subgroups of the 


\begin{tabular}{|c|c|c|c|c|c|c|}
\hline Dimensions & Indicators & Data platforms & Frequency & $\begin{array}{l}\text { Responsible } \\
\text { agencies }\end{array}$ & Level & Availability \\
\hline \multirow[t]{3}{*}{ Inputs } & $\begin{array}{l}\text { 1. Financing ( } 8 \\
\text { indicators) }\end{array}$ & $\begin{array}{l}\text { - Household Income } \\
\text { and Expenditure } \\
\text { Survey (HIE); } \\
\text { - National Health } \\
\text { Account (NHA) }\end{array}$ & $\begin{array}{l}\text { - HIE: Annually } \\
\text { since } 1963 \\
\text { - NHA: Annually, } \\
\text { since } 2000\end{array}$ & $\begin{array}{l}\text { - NSC (National } \\
\text { Statistics Center) }\end{array}$ & $\begin{array}{l}\text { National, } \\
\text { urban/rural, } \\
\text { by wealth quintiles }\end{array}$ & Available \\
\hline & $\begin{array}{l}2 . \\
\text { Infrastructure } \\
\text { and health } \\
\text { workforce (6 } \\
\text { indicators) }\end{array}$ & $\begin{array}{l}\text { - Services Availability } \\
\text { and Readiness } \\
\text { Assessment Survey } \\
\text { (SARA); } \\
\text { - Routine Information } \\
\text { System (RHS); }\end{array}$ & $\begin{array}{l}\text { - SARA: has } \\
\text { not been } \\
\text { implemented yet }\end{array}$ & - MoHME & $\begin{array}{l}\text { National, } \\
\text { provincial, }\end{array}$ & $\begin{array}{l}\text { SARA has not been } \\
\text { conduct yet; data } \\
\text { before HTP (2014) } \\
\text { are not available; }\end{array}$ \\
\hline & $\begin{array}{l}\text { 3. Health } \\
\text { Information } \\
\text { System }(2 \\
\text { indicators })\end{array}$ & $\begin{array}{l}\text { - Services Availability } \\
\text { and Readiness } \\
\text { Assessment Survey } \\
\text { (SARA); } \\
\text { - Routine Information } \\
\text { System (RIS); }\end{array}$ & $\begin{array}{l}\text { - SARA: has } \\
\text { not been } \\
\text { implemented yet }\end{array}$ & - MoHME & $\begin{array}{l}\text { National, } \\
\text { provincial, }\end{array}$ & $\begin{array}{l}\text { SARA has not been } \\
\text { conduct yet }\end{array}$ \\
\hline \multirow[t]{3}{*}{ Outputs } & $\begin{array}{l}\text { 1. Access and } \\
\text { coverage of } \\
\text { health services } \\
\text { (outpatient, } \\
\text { inpatient and } \\
\text { primary health } \\
\text { care services) } \\
\text { (15 indicators) }\end{array}$ & $\begin{array}{l}\text { - Utilization Health } \\
\text { Services Survey (UHS); } \\
\text { - Iranian Multiple } \\
\text { Indicators of } \\
\text { Demographic and } \\
\text { Health Survey } \\
\text { (IrMIDHS); } \\
\text { - Access to Essential } \\
\text { Medicine and Vaccine } \\
\text { (EM\&V): }\end{array}$ & $\begin{array}{l}\cdot \text { UHS: } 2003 \text {, } \\
\text { 2008,2014 and } \\
\text { 2014; } \\
\text { - IrMIDHS: 1999, } \\
\text { 2010 and 2015; } \\
\text { EM\&V: has } \\
\text { not been } \\
\text { implemented yet }\end{array}$ & $\begin{array}{l}\cdot \text { NIHR } \\
\cdot \text { NSC }\end{array}$ & $\begin{array}{l}\text { National, } \\
\text { urban/rural, } \\
\text { by wealth quintiles }\end{array}$ & $\begin{array}{l}\text { EM\&V has not } \\
\text { been conducted } \\
\text { yet }\end{array}$ \\
\hline & $\begin{array}{l}\text { 2. Utilization } \\
\text { of health } \\
\text { services ( } 5 \\
\text { indicators) }\end{array}$ & $\begin{array}{l}\text { - Iranian Multiple } \\
\text { Indicators of } \\
\text { Demographic and } \\
\text { Health Survey } \\
\text { (IrMIDHS); } \\
\text { - Routine Information } \\
\text { System (RIS); }\end{array}$ & $\begin{array}{l}\text { IrMIDHS: 1999, } \\
2010 \text { and 2015; } \\
\text { RIS: annually. }\end{array}$ & $\begin{array}{l}\cdot \text { NIHR } \\
\cdot \text { NSC } \\
\cdot \text { MoHME }\end{array}$ & $\begin{array}{l}\text { National, } \\
\text { urban/rural, } \\
\text { by wealth quintiles }\end{array}$ & $\begin{array}{l}\text { Not available for } \\
\text { all indicators and } \\
\text { levels }\end{array}$ \\
\hline & $\begin{array}{l}\text { 3. Service } \\
\text { quality and } \\
\text { safety } \\
\text { (10 indicators) }\end{array}$ & $\begin{array}{l}\text { - Iranian Multiple } \\
\text { Indicators of } \\
\text { Demographic and } \\
\text { Health Survey } \\
\text { (IrMIDHS); } \\
\text { - Routine Information } \\
\text { System (RIS); }\end{array}$ & $\begin{array}{l}\text { IrMIDHS: 1999, } \\
2010 \text { and 2015; } \\
\text { RIS: annually. }\end{array}$ & $\begin{array}{l}\cdot \text { NIHR } \\
\cdot \text { NSC } \\
\cdot \text { MoHME }\end{array}$ & $\begin{array}{l}\text { National, } \\
\text { urban/rural, } \\
\text { by wealth quintiles }\end{array}$ & $\begin{array}{l}\text { Not available for } \\
\text { all indicators and } \\
\text { levels }\end{array}$ \\
\hline \multirow[t]{2}{*}{ Outcomes } & $\begin{array}{l}\text { 1. Effective } \\
\text { coverage of } \\
\text { services } \\
\text { (13 indicators) }\end{array}$ & $\begin{array}{l}\text { - Utilization Health } \\
\text { Services Survey (UHS); } \\
\text { - Iranian Multiple } \\
\text { Indicators of } \\
\text { Demographic and } \\
\text { Health Survey } \\
\text { (IrMIDHS); } \\
\text { - STEPwise approach to } \\
\text { surveillance (STEPS); } \\
\text { - Some specific studies } \\
\text { (not determined) }\end{array}$ & $\begin{array}{l}\text { UHS: } 2003 \text {, } \\
\text { 2008,2014 and } \\
\text { 2014; } \\
\text { - IrMIDHS: 1999, } \\
\text { 2010 and 2015; } \\
\text { - STEPs: annually } \\
\text { or biannually } \\
\text { since 2005 }\end{array}$ & $\begin{array}{l}\cdot \text { NIHR } \\
\text { - MoHME }\end{array}$ & $\begin{array}{l}\text { National, } \\
\text { urban/rural, } \\
\text { by wealth quintiles }\end{array}$ & $\begin{array}{l}\text { Not available for } \\
\text { all indicators and } \\
\text { levels }\end{array}$ \\
\hline & $\begin{array}{l}\text { 2. Health risk } \\
\text { factors } \\
\text { (12 indicators) }\end{array}$ & $\begin{array}{l}\text { - Utilization Health } \\
\text { Services Survey (UHS); } \\
\text { - Iranian Multiple } \\
\text { Indicators of } \\
\text { Demographic and } \\
\text { Health Survey } \\
\text { (IrMIDHS); } \\
\text { - Routine Information } \\
\text { System (RIS); } \\
\text { - Some specific studies } \\
\text { (not determined); }\end{array}$ & $\begin{array}{l}\text { - UHS: } 2003 \text {, } \\
\text { 2008,2014 and } \\
\text { 2014; } \\
\text { - IrMIDHS: 1999, } \\
\text { 2010 and 2015; } \\
\text { - STEPs: annually } \\
\text { or biannually } \\
\text { since 2005 }\end{array}$ & $\begin{array}{l}\cdot \text { NIHR } \\
\text { - MoHME }\end{array}$ & $\begin{array}{l}\text { National, } \\
\text { urban/rural, } \\
\text { by wealth quintiles }\end{array}$ & \\
\hline
\end{tabular}




\begin{tabular}{|c|c|c|c|c|c|c|}
\hline Dimensions & Indicators & Data platforms & Frequency & $\begin{array}{l}\text { Responsible } \\
\text { agencies }\end{array}$ & Level & Availability \\
\hline \multirow[t]{3}{*}{ Impacts } & $\begin{array}{l}\text { 1. Health } \\
\text { status } \\
\text { (11 indicators) }\end{array}$ & $\begin{array}{l}\text { - Iranian Multiple } \\
\text { Indicators of } \\
\text { Demographic and } \\
\text { Health Survey } \\
\text { (IrMIDHS); } \\
\text { - Routine Information } \\
\text { System (RIS); } \\
\text { - STEPwise approach to } \\
\text { surveillance (STEPS); } \\
\text { - Some specific studies } \\
\text { (not determined) }\end{array}$ & $\begin{array}{l}\text { - IrMIDHS: } 1999 \text {, } \\
2010 \text { and } 2015 ; \\
\text { - STEPs: annually } \\
\text { or biannually } \\
\text { since } 2005\end{array}$ & $\begin{array}{l}\cdot \text { NIHR } \\
\cdot \text { MoHME }\end{array}$ & $\begin{array}{l}\text { National, } \\
\text { urban/rural, } \\
\text { by wealth quintiles }\end{array}$ & $\begin{array}{l}\text { Not available for } \\
\text { all indicators and } \\
\text { levels }\end{array}$ \\
\hline & $\begin{array}{l}\text { 2. Financial } \\
\text { risk protection } \\
\text { ( } 2 \text { indicators) }\end{array}$ & $\begin{array}{l}\text { - Household Income } \\
\text { and Expenditure } \\
\text { Survey (HIE); }\end{array}$ & $\begin{array}{l}\text { - HIE: Annually } \\
\text { since } 1990 \text { (with } \\
\text { new method) }\end{array}$ & - NSC & $\begin{array}{l}\text { National, } \\
\text { urban/rural, } \\
\text { by wealth quintiles }\end{array}$ & Available \\
\hline & $\begin{array}{l}\text { 3. Satisfaction } \\
\text { of health } \\
\text { services ( } 3 \\
\text { indicators) }\end{array}$ & $\begin{array}{l}\text { - Utilization Health } \\
\text { Services Survey (UHS); } \\
\text { - Patient and provider's } \\
\text { satisfaction survey; }\end{array}$ & $\begin{array}{l}\text { - UHS: } 2003 \text {, } \\
\text { 2008,2014 and } \\
\text { 2014; } \\
\text { - IrMIDHS }\end{array}$ & - NIHR & $\begin{array}{l}\text { National, } \\
\text { urban/rural, } \\
\text { by wealth quintiles }\end{array}$ & $\begin{array}{l}\text { Not available } \\
\text { before HTP }\end{array}$ \\
\hline
\end{tabular}

Table 2: Characteristics of the surveys required to obtain the M\&E indicators

\begin{tabular}{|c|c|c|c|c|}
\hline Study & Aim & Frequency & Consideration & $\begin{array}{l}\text { Survey } \\
\text { quality } \\
\text { assessment } \\
\text { evidence }\end{array}$ \\
\hline $\begin{array}{l}\text { National Health } \\
\text { Accounts (NHA) }\end{array}$ & $\begin{array}{l}\text { NHA provides answers to the following questions: } 1 \text { ) what is the } \\
\text { total expenditure on health in a country? 2) Who pays for health } \\
\text { care services? 3) How much is spent on health services? 4) How } \\
\text { much is paid to different health service providers? (11) }\end{array}$ & $\begin{array}{l}\text { Annually, since } \\
2000\end{array}$ & $\begin{array}{l}\text { National } \\
\text { Statistics } \\
\text { Centre of Iran } \\
\text { is responsible } \\
\text { body to conduct } \\
\text { the survey }\end{array}$ & Not defined \\
\hline $\begin{array}{l}\text { Household Income and } \\
\text { Expenditure Survey } \\
\text { (HIES) }\end{array}$ & $\begin{array}{l}\text { The HIES aims to hand in estimates of the average income and } \\
\text { expenditure for urban and rural households at provincial and } \\
\text { country levels. To investigate the household health expenditures, } \\
\text { the data relevant to inpatient and outpatient expenditures from } \\
2012 \text { to } 2014 \text {, collected by households' Income and Expenditure } \\
\text { Survey in rural and urban areas, were analyzed by the NIHR (39). }\end{array}$ & $\begin{array}{l}\text { Annually, since } \\
1990 \text { (with new } \\
\text { method) }\end{array}$ & $\begin{array}{l}\text { National } \\
\text { Statistics Centre } \\
\text { of Iran is the } \\
\text { responsible } \\
\text { body to conduct } \\
\text { the survey }\end{array}$ & Not defined \\
\hline $\begin{array}{l}\text { Services Availability } \\
\text { and Readiness } \\
\text { Assessment (SARA) }\end{array}$ & $\begin{array}{l}\text { The survey objective is to generate reliable and regular } \\
\text { information on service delivery (such as the availability of key } \\
\text { human and infrastructure resources), on the availability of basic } \\
\text { equipment, basic amenities, essential medicines, and diagnostic } \\
\text { capacities, and on the readiness of health facilities to provide } \\
\text { basic health-care interventions relating to family planning, child } \\
\text { health services, basic and comprehensive emergency obstetric } \\
\text { care, HIV, TB, malaria, and noncommunicable diseases (40). }\end{array}$ & Not defined & $\begin{array}{l}\text { National } \\
\text { Institute } \\
\text { of Health } \\
\text { Research is the } \\
\text { responsible } \\
\text { body to conduct } \\
\text { the survey }\end{array}$ & Not defined \\
\hline $\begin{array}{l}\text { Utilization Health } \\
\text { Survey (UHS) }\end{array}$ & $\begin{array}{l}\text { The most important aims of the survey are: 1) To measure the } \\
\text { need of the population for health services; } 2 \text { ) To find out what } \\
\text { steps people take in receiving the health services; } 3 \text { ) To find out } \\
\text { what type of services the households receive; } 4 \text { ) To determine } \\
\text { how much time and expenses are spent on health services; 5) To } \\
\text { address the extent of people's satisfaction with health services } \\
(22) \text {. }\end{array}$ & $\begin{array}{l}\text { Quadrennial or } \\
\text { triennial, since } \\
2002\end{array}$ & $\begin{array}{l}\text { Four rounds } \\
\text { have been } \\
\text { performed in } \\
\text { I.R. Iran (2002, } \\
\text { 2008, } 2014 \text { and } \\
\text { 2015). }\end{array}$ & Not defined \\
\hline $\begin{array}{l}\text { Iranian Multiple } \\
\text { Indicators of } \\
\text { Demographic and } \\
\text { Health (IrMIDHS) }\end{array}$ & $\begin{array}{l}\text { The primary objectives of the IrMIDHS are: } 1 \text { ) To provide rigorous } \\
\text { data on health and population at the national and provincial } \\
\text { levels for assessing a range of social indicators and their } \\
\text { influences on health, especially on children and women situation } \\
\text { in I.R. Iran; } 2 \text { ) To provide data needed for monitoring progress } \\
\text { toward the goals established in national plans and priorities and } \\
\text { the MDGs; } 3 \text { ) To assist policy-makers and programme managers } \\
\text { in designing effective strategies to promote health outcomes and } \\
\text { equity in access to health care (41). }\end{array}$ & $\begin{array}{l}\text { Quadrennial, } \\
\text { since } 2000\end{array}$ & $\begin{array}{l}\text { Four rounds } \\
\text { have been } \\
\text { performed in } \\
\text { I.R. Iran (2000, } \\
2010 \text { and 2015) }\end{array}$ & Not defined \\
\hline
\end{tabular}




\begin{tabular}{|c|c|c|c|c|}
\hline Study & Aim & Frequency & Consideration & $\begin{array}{l}\text { Survey } \\
\text { quality } \\
\text { assessment } \\
\text { evidence }\end{array}$ \\
\hline $\begin{array}{l}\text { STEPwise approach } \\
\text { to surveillance of } \\
\text { noncommunicable } \\
\text { diseases } \\
\text { (STEPs) }\end{array}$ & $\begin{array}{l}\text { The main aim of the survey are: } 1 \text { ) To provide national and } \\
\text { provincial reliable and up-to-date information resources on risk } \\
\text { factors to map prevalence, trend and distribution of diseases; } \\
\text { 2) To prepare a tool for evidence-based public health decision- } \\
\text { making with the ultimate aim of containing and reducing the } \\
\text { emerging epidemic of noncommunicable diseases (NCDs), 3) } \\
\text { To prepare a supportive infrastructure for NCDs preventive } \\
\text { research; 4) To promote the level of knowledge, reinforcement } \\
\text { and enlargement of public health capacity in NCD prevention } \\
\text { and PHC services (42). }\end{array}$ & $\begin{array}{l}\text { Annually, since } \\
2005\end{array}$ & $\begin{array}{l}\text { Seven rounds } \\
\text { have been } \\
\text { performed } \\
\text { in I.R. Iran } \\
\left(2005^{-2009,}\right. \\
2011 \text { and 2015) }\end{array}$ & Not defined \\
\hline $\begin{array}{l}\text { Surveys for } \\
\text { determining the } \\
\text { effective coverage of } \\
\text { health services }\end{array}$ & $\begin{array}{l}\text { To provide related effective coverage indicators, a country should } \\
\text { conduct several studies. The indicators include prevention, } \\
\text { treatment, rehabilitation and palliation services based on global } \\
\text { UHC framework recommendation (33). }\end{array}$ & Not defined & Not defined & Not defined \\
\hline Satisfaction surveys & $\begin{array}{l}\text { The measurement of patient experiences is an important } \\
\text { component of health services evaluation. }\end{array}$ & Not defined & Not defined & Not defined \\
\hline
\end{tabular}

population. If only the national averages of health indicators are monitored, they may not fully represent the changes in the health of a population. It means that there was lack of disaggregated information to undertake an equity-focused analysis of information and its use to refine policy-making and implementation.

\section{Discussion}

The current study was carried out in order to develop the most appropriate M\&E framework for the HTP and to identify M\&E data gaps. The M\&E framework of the HTP was designed in accordance with the recommendations by the global guidance for UHC measuring and monitoring in country contexts. Appropriate data sources for measuring the indicators of the agreed $M \& E$ framework were determined accordingly.

According to the results of the current study, there were no appropriate data sources for some of the proposed indicators. Hence, to track the progress of UHC, a series of nationally representative surveys should be designed and implemented (19). Over the past two decades, most countries have implemented various health sector reforms to address gaps in access, equity, and effectiveness of health systems $(19,20)$. Countries with effective M\&E frameworks to evaluate the success of the reforms have almost all reported successful results towards achieving the reform goals. Some of them have successfully used the M\&E framework for the UHC to assess the achievements of health sector reforms (24-30). The fact that the goals of the recent health reforms are in accordance with the UHC aims and objectives can be regarded as a great opportunity for the Iranian health system in making headway toward UHC.

Furthermore, the most important components of the UHC (i.e. effective coverage of services and protection against financial risks) (20) have been addressed in the fifth and sixth development plans of the country (16). The designing of the M\&E framework for the HTP revealed that the health information system was currently experiencing several challenges, limiting its capacity to generate the required information for tracing the framework indicators. In other words, although the Islamic Republic of Iran ranked 17th in terms of science production in the world in 2012 (31), there was lack of valid and reliable data for the monitoring and evaluation of macro-policies. To give an example, seven rounds of the Integrated Monitoring Evaluation Survey System Study (IMES) aimed at assessing the reproductive health needs have been conducted in the country (32). However, due to lack of focus on equity, data on socio-economic status of participants were not obtained and analysed in these studies. As a result, they could not generate reliable evidence to refine policies and programmes and thereby reduce inequities in service access and coverage, as well as in health and well-being.

The framework indicators can be obtained from two main resources: the national surveys and the routine information system (19). To capture these indicators, nine or more national studies are required in general. Some of these studies are yet to be designed and conducted in the country (e.g. effective coverage surveys or SARA). Effective coverage is defined as the fraction of potential health gain that is actually delivered to the population through the health system, given its capacity (33). Effective coverage studies should have several substudies, depending on the selected indicators.

As for the surveys already conducted (e.g. Utilization Health Survey, IrMIDHS, STEPs), it should be noted that, until now, there is no data access policy to provide an overview of technical, legal and ethical issues related to the dissemination of the surveys' micro-data for research purposes. As a result, many national studies produced only descriptive reports after difficult and timeconsuming work, resulting in limited data utilization for policy-making and planning. The NIHR developed a data 
access policy, which made data potentially available for statistical purposes to public-good researchers working within academic institutions, government agencies, and the wider health sector, subject to certain conditions. This was the first public official release of the survey data in the Islamic Republic of Iran (34). Some studies such as patient satisfaction surveys were designed and conducted following the launch of the HTP. The study investigates the satisfaction of inpatients in MoHMEaffiliated hospitals with a small sample size. After the framework development, the investigation needs to be undertaken with a larger sample size that would better reflect the Iranian population $(15,17)$.

The routine information system is another valuable data source to track some of the M\&E framework indicators. Strengthening and harmonizing data collection through surveys and health facility reporting systems are critical for the monitoring of UHC $(1,35)$. A health information system is a crucial component for the successful monitoring of the UHC objectives $(19,28,35)$. Currently, the routine information system does not provide accurate and complete data in a timely manner (36). Routine data from the private health sector is not captured through the national health information system. Although a considerable volume of electronic data exists, they are fragmented and unsuitable for used in policy and decision-making. The implementation of the proposed framework is dependent on the functionality of the country's health information system. Therefore, there is an urgent need for strengthening the country's health information system in order to successfully monitor and evaluate both the HTP and UHC.

National surveys are often the main data source for tracking UHC achievements. They can provide accurate population statistics on the coverage of services and financial protection, disaggregated according to socioeconomic status, place of residence, sex, and other relevant variables $(19,20)$. National household surveys are currently being conducted in the Islamic Republic of Iran without any determined frequency. The frequency of conducting these surveys is the most important current challenge that should be addressed according to the current data needs and available budget (7). A key consideration in measuring progress toward UHC is data quality (35), which is definitely critical to the success of the proposed M\&E framework. Data are generally considered of high quality if they are accurate, complete, consistent, accessible, and timely. Data quality evaluation is crucial if we are to draw out relevant and accurate information from health surveys. There are some guidelines and methods available for measuring and assessing survey quality. Data, data use, and the data collection process are the three aspects of data quality that should be assessed to assure overall data quality. We did not find any published evidence that showed whether the quality of previous household surveys had been evaluated. Therefore, it is critical to assign an external observer body or organization to evaluate survey quality in the Islamic Republic of Iran (37).
The results indicate that there is no guideline to determine the periodicity of the national surveys. It is not clear when, and based on what needs, household surveys should be carried out. On the other hand, ongoing surveys are inconsistent in questions assessing a specific topic (e.g. assessing households' socio-economic status). In this case, the equity analyses using different sources may not get the same answer (21). The developed framework can increase the consistency of the surveys for more appropriate comparisons. Owing to lack of a well-developed plan for conducting national surveys, household surveys cannot currently be considered as a reliable source to address questions of whether the HTP objectives have been achieved or whether the country has moved ahead in a positive direction toward achieving the UHC goals. The global UHC framework for countries (19) stipulates that the frequency of surveys should be clear in all national studies. Besides, they ought to be conducted based on the countries' needs every 1-5 years. The experiences of other countries demonstrate that the frequency of monitoring and evaluation should be decided while designing monitoring frameworks $(20,25,26,30,35)$. According to these studies, the frequency of monitoring and evaluation of health reforms should be determined based on the availability of data. If routine data sources can generate information of acceptable quality, they would be good enough for the monitoring process. Evaluation usually investigates the long-term effects of reforms. Therefore, information generated by health surveys, carried-out almost every five years, may meet the information requirements for evaluation.

If the contents of a survey are insufficient to meet evaluation needs, special studies should be done $(1,20)$. The results showed that the available household surveys did not meet the requirements of the M\&E framework. Hence, new studies are needed, particularly to investigate indicators that are not currently measured, e.g., the effective coverage of health care interventions. Such studies should be conducted at an appropriate and reasonable frequency. A clear suggestion is that in the initial years of the reform, frequency of conducting national surveys should not be more than five years to avoid any problem in monitoring and evaluation of the reform goals due to low quality or unavailability of data. Since the achievement of the UHC goals by 2025 is a country commitment (38), the Islamic Republic of Iran urgently needs to strengthen the health information system in order to generate reliable data to monitor progress.

The application of the M\&E framework not only provides a strong updated information system but also produces timely and high quality evidence for policymakers. It can help in building capacity, empowering skilled human resources. In turn, this ensures a sustainable supply of logistics required to support the availability and quality of routine data, and supports linkages between academic and research institutions. 


\section{Conclusion}

The designing of the M\&E framework for the HTP sheds light on the importance of further Investment in the health information system. The framework and the indicators' list were guided by international priorities and designed in a way to be adaptable to the country context and the health sector development programme. The proposed M\&E framework would facilitate successful M\&E of both the HTP and UHC. An adequate measurement of the progress toward the UHC would require investment in the health information system. The development of the M\&E framework indicators revealed that at least nine national household surveys were required to generate indicators for an effective monitoring of the HTP. The development of a guideline that specifies the frequency of the surveys along with the ways to coordinate these surveys can, thus, be very helpful in realizing the objectives of the framework. The formulation of the data access policy may increase the use of survey data in policy and practice. Some Important points are:

- Considering the HTP objectives, the M\&E framework for the UHC is the most appropriate M\&E framework;

- the designed M\&E framework and the indicator list were not only adaptable to the country but also ena- bled the health system to benchmark progress toward the UHC at the global level;

- to monitor and evaluate the HTP, only half of the indicators could be captured at the end of first year of the HTP implementation. Some of the available indicators were not updated at the time of framework designing and no appropriate data sources were available for the rest;

- the proposed M\&E framework can provide a proper path to implement the HTP at least for five years ahead;

- investment is required to strengthen the capacity of the information health system in order to generate high quality information for monitoring progress toward the UHC; and

- the information gap hampering the monitoring of the progress towards the UHC should be addressed through regular and periodic surveys that capture all the dimensions of UHC.

- Applying the M\&E framework can strengthen and manage the health information system properly, empower skilled human resources and support interaction between researchers and scientific centers.

\section{Acknowledgements}

Authors would like to thanks colleagues at the MoHME for reviewing the framework.

Funding: None.

Competing interests: None declared.

\section{Élaboration d'un cadre d'action pour le suivi et l'évaluation du Plan de transformation sanitaire en République islamique d'Iran : enseignements tirés \\ Résumé}

Contexte : Le suivi et l'évaluation des réformes des systèmes de santé sont essentiels pour garantir la bonne réalisation des objectifs que celles-ci se sont fixés. La dernière réforme du système de santé en République islamique d'Iran, appelée Plan de transformation sanitaire, a été lancée en 2014. La République islamique d'Iran a commencé à mettre en œuvre ce plan en vue de réaliser la couverture sanitaire universelle (CSU).

Objectifs : La présente étude avait pour objectif d'élaborer un plan d'action de suivi et d'évaluation du Plan de transformation sanitaire le plus approprié qui soit, conformément aux priorités et aux objectifs mondiaux et nationaux, ainsi que d'identifier les lacunes à combler en matière de données concernant ce processus de suivi et d'évaluation.

Méthodes : Une étude de cas et une approche reposant sur des bases factuelles ont été appliquées pour le cadre susmentionné. Le modèle proposé par la Banque mondiale et l'Organisation mondiale de la Santé (OMS) pour le suivi et l'évaluation de la couverture sanitaire universelle (CSU) a été utilisé pour servir de base à une liste possible d'indicateurs. Des documents d'orientation clés ont ainsi été passés en revue. Le processus de formulation du cadre d'action a été mené au moyen d'une série de réunions entre experts et hauts responsables travaillant dans différents départements du ministère de la Santé et de l'Éducation médicale dont les perspectives sur la fonctionnalité et l'utilisation du cadre d'action étaient considérées comme utiles. Le projet final a été présenté aux responsables de l'élaboration des politiques en vue d'obtenir leurs contributions et leur approbation.

Résultats : Une cartographie des données a révélé qu'au moins neuf études nationales étaient requises pour obtenir les indicateurs permettant un suivi efficace. À l'étape de la conception du cadre d'action, de nombreux indicateurs n'étaient pas disponibles ou n'avaient pas été mis à jour depuis plusieurs années du fait de l'absence de source de données fiables. 
Conclusions : Les résultats ont indiqué que le système d'information sanitaire du pays comportait de nombreuses lacunes nécessitant d'être comblées afin de permettre d'évaluer les progrès effectués sur la voie de la réalisation des objectifs de la CSU et d'appréhender la réussite du plan. La mise en œuvre du cadre d'action proposé permettrait d'augmenter la comparabilité des indicateurs sanitaires du pays au niveau mondial et de préciser la voie à emprunter pour atteindre les objectifs annoncés dans la réforme.

\section{وضع إطار عمل لمراقبة وتقييم خطة التحول الصحي في جمهورية إيران الإسلامية: الدروس المستفادة جالة عبدي، رضا بجدزادة، إلهام أحمدنجاد}

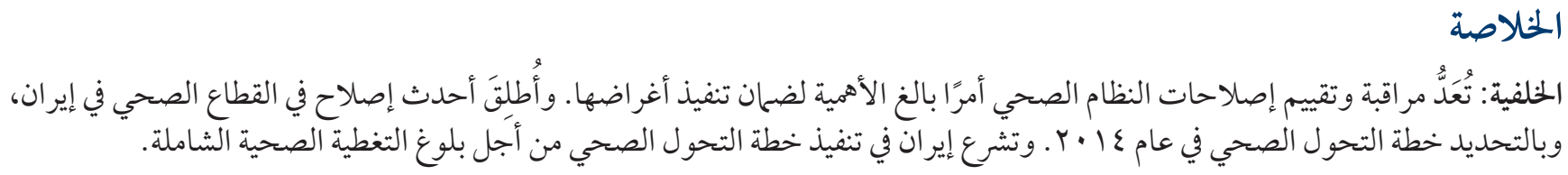

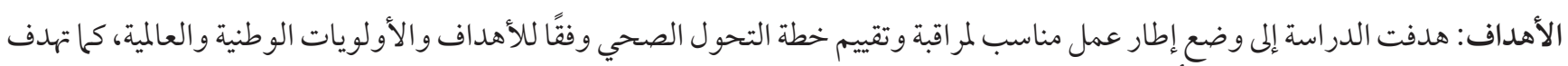

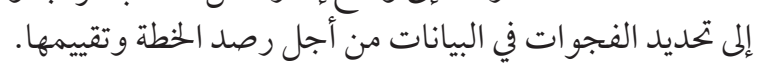

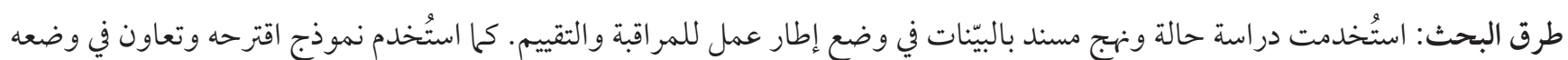

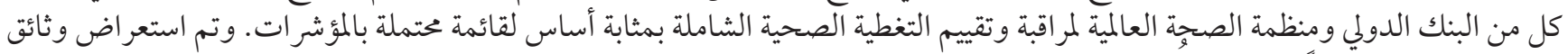

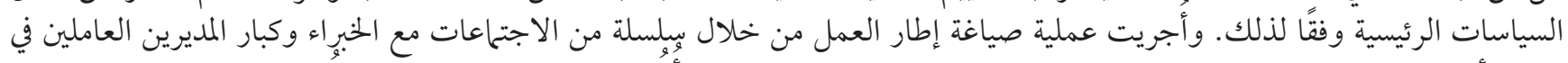

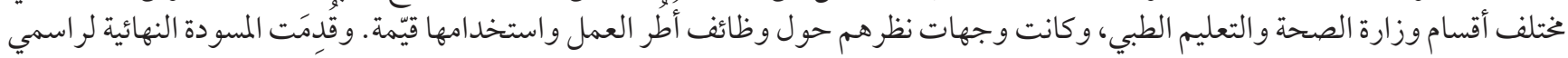
السياسات لتقديم مدخلاتهم و المو افقة عليها.

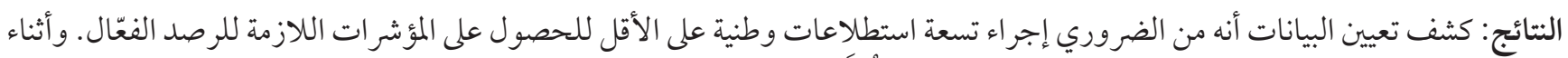

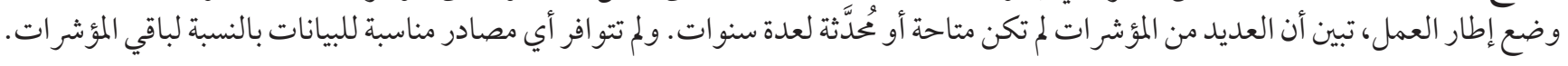

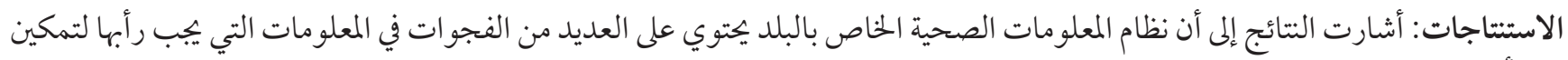

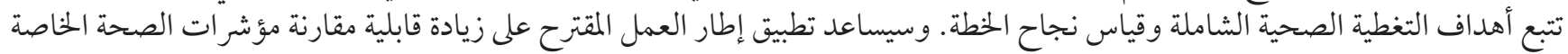

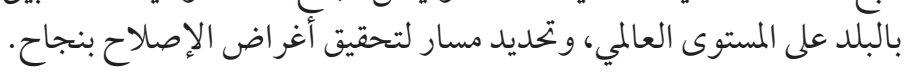

\section{References}

1. Giedion UA. Eduardo Andres; Diaz, Yadira. The impact of universal coverage schemes in the developing world : a review of the existing evidence, Universal Health Coverage (UNICO) studies series. Washington DC: World Bank; 2013.

2. Boerma T, AbouZahr C, Evans D, Evans T. Monitoring intervention coverage in the context of universal health coverage. PLoS Med. 2014;11(9):e1001728. Epub 2014/o9/23. https://doi.org/10.1371/journal.pmed.1001728. PMID: 25243586; PMCID: PMCPmc4171108.

3. I.R.Iran's national scientific roadmap. Higher Council of Cultural Revolution Web site. (http://www.iranculture.org/fa/Default. aspx?current=viewDoc\&currentID=736, accessed 10 December, 2011).

4. Iranian General Health Polices. (http://ird.behdasht.gov.ir/index.aspx?siteid=419\&pageid=51060\&newsview=106249, accessed 1 December 2015).

5. Rajabi F, Esmailzadeh H, Rostamigooran N, Majdzadeh R, Doshmangir L. Future of Health Care Delivery in Iran, Opportunities and Threats. Iranian Journal of Public Health. 2013;42(Supple1):23-30. PMID: PMC3712596.

6. World Bank. Islamic Republic of Iran - Health Sector Review : Volume 1. Main Report. Washington DWB. Washington DC: World Bank; 2008 (http://hdl.handle.net/10986/7960, accessed 1 December 2015).

7. Eastern Mediterranean Region. Framework for health information systems and core indicators for monitoring health situation and health system performance, 2015 [updated 2015]. (http://applications.emro.who.int/dsaf/EMROPUB_2015_EN_1904.pdf?ua=1, accessed 1 December 2015).

8. National Institute of Health Research. Islamic Republic of Iran. Universal Health Coverage in Iran. Vol First. Tehran, Iran: Gozineh Parsian Teb; 2015. (http://nihr.tums.ac.ir/wp-content/uploads/2015/08/uhc-book-edit1.pdf, accessed August 8, 2015).

9. Fazaeli AA, Seyedin H, Vosoogh Moghaddam A, Delavari A, Salimzadeh H, Varmazyar H, et al. Fairness of Financial Contribution in Iranian Health System: Trend Analysis of National Household Income and Expenditure, 2003-2010. Glob J Health Sci. 2015;7(5):260-5. http://dx.doi.org/10.5539/gjhs.v7n5p260

10. Hajizadeh M, Nghiem HS. Out-of-pocket expenditures for hospital care in Iran: who is at risk of incurring catastrophic payments? Int J Health Care Finance Econ. 2011;11(4):267-85. http://dx.doi.org/10.1007/s10754-011-9099-1 
11. Statistical center of Iran. Iran National Health Accounts, 2002-2008. (https://www.amar.org.ir/Portals/o/topics/sna/hesab_salamat.pdf, accessed 21 August, 2015. Published 2011).

12. Kavosi Z, Keshtkaran A, Hayati R, Ravangard R, Khammarnia M. Household financial contribution to the health System in Shiraz, Iran in 2012. International journal of health policy and management. 2014;3(5):243-9. Epub 2014/10/23. https://doi. org/10.15171/ijhpm.2014.87. PMID: 25337598; PMCID: PMCPmc4204743.

13. Bagheri Lankarani K, Ghahramani S, Zakeri M, Joulaei H. Lessons Learned From National Health Accounts in Iran: Highlighted Evidence for Policymakers. Shiraz E-Med J. 2015;16(4):e27868. Epub 2015-04-23. https://doi.org/10.17795/semj27868.

14. Moradi-Lakeh M, Vosoogh-Moghaddam A. Health Sector Evolution Plan in Iran; Equity and Sustainability Concerns. International journal of health policy and management. 2015;4(10):637-40. Epub 2015/12/18. https://doi.org/10.15171/ijhpm.2015.160. PMID: 26673172; PMCID: PMCPmc4594102.

15. National Institute of Health Research. Islamic Republic of Iran. Monitoring of Health Sector Evolution Plan, Report 1. (http:// nihr.tums.ac.ir/wp-content/uploads/2015/04/file3.pdf, accessed 28 January, 2016).

16. The Fifth national development program. Parliament of Islamic Republic of Iran Website. (http://parliran.ir/index.aspx?siteid=1\&siteid=1\&pageid=3362, accessed December 10, 2015).

17. National Institute of Health Research. Islamic Republic of Iran. Monitoring of Health Sector Evolution Plan, Reports 3. (http:// nihr.tums.ac.ir/wp-content/uploads/2015/04/Satisfaction-3.pdf, accessed 28 January, 2016).

18. Monitoring Progress towards Universal Health Coverage at Country and Global Levels: A Framework. Geneva: World Health Organization; 2013 (http://www.who.int/healthinfo/country_monitoring_evaluation/UHC_WBG_DiscussionPaper_Dec2013.pdf).

19. Boerma T, Eozenou P, Evans D, Evans T, Kieny M-P, Wagstaff A. Monitoring Progress towards Universal Health Coverage at Country and Global Levels. PLoS Medicine. 2014;11(9):e1001731. https://doi.org/10.1371/journal.pmed.1001731. PMID: PMC4171369.

20. World Health Organization. The world health report - health systems financing: the path to universal coverage. Geneva: World Health Organization; 2010 (http://www.who.int/whr/en/index.html, accessed 29 April 2014).

21. Hosseinpoor AR, Bergen N, Koller T, Prasad A, Schlotheuber A, Valentine N, et al. [Equity-oriented monitoring in the context of universal health coverage]. Revista panamericana de salud publica = Pan. Am J Public Health. 2015;38(1):17-27. Epub 2015/10/28.

22. National Institute of Health Research. Islamic Republic of Iran. Utilization Health Survey, Report. (http://nihr.tums.ac.ir, accessed January 28, 2016).

23. National Institute of Health Research. Islamic Republic of Iran. Iran's Multiple Indicators Demographics and Health Survey, 2015 (http://nihr.tums.ac.ir, accessed 28 January, 2016).

24. Huda T, Khan JA, Ahsan KZ, Jamil K, El Arifeen S. Monitoring and evaluating progress towards Universal Health Coverage in Bangladesh. PLoS Med. 2014;11(9):e1001722. Epub 2014/09/23. https://doi.org/10.1371/journal.pmed.1001722. PMID: 25244599; PMCID: PMCPmc4170958.

25. Barreto ML, Rasella D, Machado DB, Aquino R, Lima D, Garcia LP, et al. Monitoring and evaluating progress towards Universal Health Coverage in Brazil. PLoS Med. 2014;11(9):e1001692. Epub 2014/09/23. https://doi.org/10.1371/journal.pmed.1001692. PMID: 25243676 PMCID: PMCPmc4171375.

26. Tangcharoensathien V, Limwattananon S, Patcharanarumol W, Thammatacharee J. Monitoring and evaluating progress towards Universal Health Coverage in Thailand. PLoS Med. 2014;11(9):e1001726. Epub 2014/09/23. https://doi.org/10.1371/journal. pmed.1001726. PMID: 25243409; PMCID: PMCPmc4171094.

27. Mtei G, Makawia S, Masanja H. Monitoring and evaluating progress towards Universal Health Coverage in Tanzania. PLoS Med. 2014;11(9):e1001698. Epub 2014/09/23. https://doi.org/10.1371/journal.pmed.1001698. PMID: 25244395; PMCID: PMCPmc4171093.

28. Alebachew A, Hatt L, Kukla M. Monitoring and evaluating progress towards Universal Health Coverage in Ethiopia. PLoS Med. 2014;11(9):e1001696. Epub 2014/09/23. https://doi.org/10.1371/journal.pmed.1001696. PMID: 25244146; PMCID: PMCPmc4171462.

29. Meng Q, Xu L. Monitoring and evaluating progress towards Universal Health Coverage in China. PLoS Med. 2014;11(9):e1001694. Epub 2014/09/23. https://doi.org/10.1371/journal.pmed.1001694. PMID: 25243903; PMCID: PMCPmc4170954.

30. Atun R, Aydin S, Chakraborty S, Sumer S, Aran M, Gurol I, et al. Universal health coverage in Turkey: enhancement of equity. Lancet (London, England). 2013;382(9886):65-99. http://dx.doi.org/10.1016/S0140-6736(13)61051-X

31. Akhondzadeh S. Iranian science shows world's fastest growth: ranks 17th in science production in 2012. Avicenna journal of medical biotechnology. 2013;5(3):139. Epub 2013/08/07. PMID: 23919116; PMCID: PMCPmc3732862.

32. Motlagh ME, Heidarzadeh A, Hashemian H, Dosstdar M. Patterns of Care Seeking During Episodes of Childhood Diarrhea and its Relation to Preventive Care Patterns: National Integrated Monitoring and Evaluation Survey (IMES) of Family Health. Islamic Republic of Iran. International journal of preventive medicine. 2012;3(1):60-7. Epub 2012/02/23. PMID: 22355479; PMCID: PMCPmc3278871.

33. Ng M, Fullman N, Dieleman JL, Flaxman AD, Murray CJ, Lim SS. Effective coverage: a metric for monitoring Universal Health Coverage. PLoS Med. 2014;11(9):e1001730. Epub 2014/09/23. https://doi.org/10.1371/journal.pmed.1001730. PMID: 25243780; PMCID: PMCPmc4171091.

34. National Institute of Health Research. Islamic Republic of Iran (http://nihr.tums.ac.ircpages/mainpage.asp?I=S1M5P2C1). 
35. Lagomarsino G, Garabrant A, Adyas A, Muga R, Otoo N. Moving towards universal health coverage: health insurance reforms in nine developing countries in Africa and Asia. Lancet. 2012 09;380(9845):933-43. http://dx.doi.org/10.1016/So140-6736(12)61147-7

36. 36. Yazdi-Feyzabadi V, Emami M, Mehrolhassani MH. Health Information System in Primary Health Care: The Challenges and Barriers from Local Providers' Perspective of an Area in Iran. International Journal of Preventive Medicine. 2015;6:57. https://doi. org/10.4103/2008-7802.160056. PMID: PMC4505398.

37. Quality dimensions, core values for OECD statistics and procedures for planning and evaluating statistical activities. Paris, Organisation for Economic Co-operation and Development, 2003 (STD/QFS(2003)1; (http://www.oecd.org/dataoecd/26/38/21687665. pdf, accessed 1 April 2010).

38. Comprehensive IR. Iran's health sector's science map. Ministry of Health \& Medical Education Web site. (http://behdasht.gov.ir/ index.aspx?siteid=1\&siteid=1\&pageid=130\&newsview=10724, accessed December 28, 2016).

39. Statistical center of Iran. Income, Expenditure Household Survey. (http://amar.org.ir/english/Metadata/Statistical-Survey/ Household-Expenditure-and-Income, accessed August 21, 2015).

40. O'Neill K, Takane M, Sheffel A, Abou-Zahr C, Boerma T. Monitoring service delivery for universal health coverage: the Service Availability and Readiness Assessment. Bulletin of the World Health Organization. 2013;91(12):923-31. Epub 2013/12/19. https://doi. org/10.2471/blt.12.116798. PMID: 24347731; PMCID: PMCPmc3845262.

41. Rashidian A, Karimi-Shahanjarini A, Khosravi A, Elahi E, Beheshtian M, Shakibazadeh E, et al. Iran's Multiple Indicator Demographic and Health Survey - 2010: Study Protocol. International journal of Preventive Medicine. 2014;5(5):632-42. Epub 2014/06/17. PMID: 24932396; PMCID: PMCPmc4050685.

42. Ministry of Health and Medical Education. STEPwise approach to chronic disease risk factor surveillance. Available at: http:// www.who.int/chp/steps/iran/en/, accessed 29 January, 2016). 


\begin{tabular}{|c|c|c|c|}
\hline Input & Output & Outcome & Impact \\
\hline $\begin{array}{l}\text { 1. Financing } \\
\text { - Total Health Expendi- } \\
\text { ture (THE) as \% Gross } \\
\text { Domestic Product (GDP) } \\
\text { - Total Health Budget (THE) } \\
\text { as \% government budget } \\
\text { - THE per capita } \\
\text { - General government health } \\
\text { expenditure per \% general } \\
\text { government expenditure } \\
\text { - Total pharmaceutical } \\
\text { expenditure per capita } \\
\text { - Fair Financial Con- } \\
\text { tribution Index } \\
\text { - \% THE by type of } \\
\text { financing agents } \\
\text { - Out of Pocket pay- } \\
\text { ment as \% THE } \\
\text { 2. Infrastructure and } \\
\text { health workforce } \\
\text { - General physician per } \\
\text { 10 ooo population } \\
\text { - Specialist per 10,0oo } \\
\text { population } \\
\text { - Paramedic per 10,00o } \\
\text { population } \\
\text { - Nurses per hospital bed } \\
\text { - Dentist per 10,0oo } \\
\text { population } \\
\text { - Hospital bed per } \\
\text { 10ooo population } \\
\text { 3. Information system } \\
\text { - Number (\%) of health facili- } \\
\text { ties has access to computer } \\
\text { with email/Internet access } \\
\text { - Number (\%) of hospitals } \\
\text { connect to the integrated } \\
\text { national health information } \\
\text { system for hospitals (HIS) }\end{array}$ & 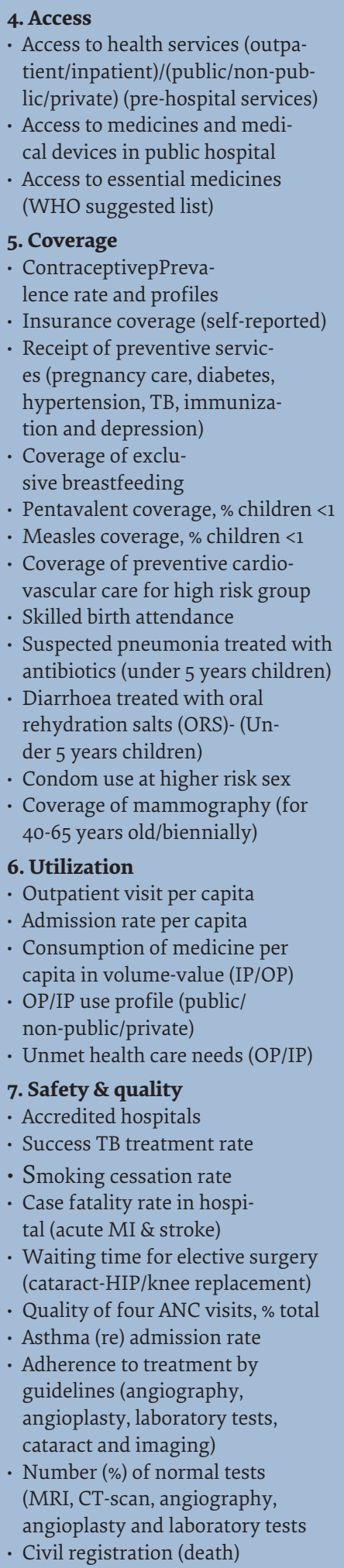 & 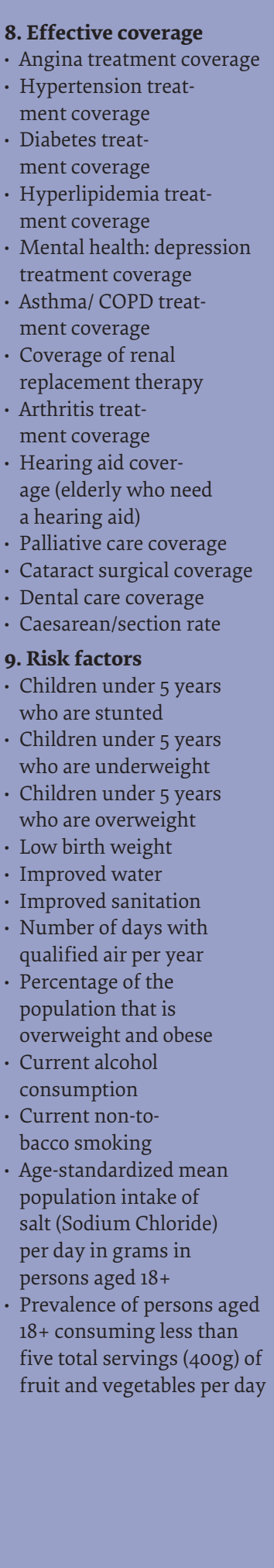 & $\begin{array}{l}\text { 10. Health status } \\
\text { - Life expectancy at birth } \\
\text { Maternal mortality ratio } \\
\text { (100,00o live births) } \\
\text { Under-5 mortality rate } \\
\text { (1000 live births) } \\
\text { Neonatal mortality rate } \\
\text { (100o live births) } \\
\text { - Self-reported health status } \\
\text { Age-standardized } \\
\text { prevalence of diabetes } \\
\text { (based on HbAic levels), } \\
\text { hypertension, cardiovas- } \\
\text { cular disease and chronic } \\
\text { respiratory disease } \\
\text { TB case detection rate } \\
\text { Survival rate of cancer } \\
\text { Survival rate of end } \\
\text { stage renal disease with } \\
\text { replacement therapy } \\
\text { Suicide rate per } \\
\text { 100,ooo population } \\
\text { Road traffic deaths per } \\
\text { 10o,ooo population } \\
\text { 11. Financial risk } \\
\text { protection } \\
\text { Catastrophic health } \\
\text { Expenditure } \\
\text { Impoverishment } \\
\text { Health expenditure } \\
\text { 12. } \\
\text { Patient satisfaction rate } \\
\text { Population satisfaction } \\
\text { (from health services) rate } \\
\text { Provider satisfaction rate }\end{array}$ \\
\hline
\end{tabular}

